with special reference to carbohydrases. Dr. Manners's current research includes work on the metabolism of human glycogen in pathological cases of glycogen storage disease, and of mammalian muscle glycogen during the development of rigor mortis. The specificity of enzymes catalysing the transfer of $\alpha$ - and $\beta$-glucosyl radicals to carbohydrate acceptors is also being examined.

\section{Sir George Beilby Memorial Awards, 1957}

The administrators of the Sir George Beilby Memorial Fund, representing the Institute of Metals, the Royal Institute of Chemistry and the Society of Chemical Industry, have awarded one hundred and fifty guineas each to Mr. B. E. Hopkins, a principal scientific officer in the Metallurgy Division of the National Physical Laboratory, in recognition of his work in physical metallurgy, with special reference to the effect of alloying elements in high-purity iron on the mechanical properties at temperatures covering the tough-to-brittle transition range under tensile and notch impact conditions ; and to Dr. E. C. Potter, of the Paint Research Station, Teddington, in recognition of his work on electrochemistry and the corrosion of metals, with special reference to the internal corrosion of power station boilers and the analysis of boiler waters for solutes at great dilution. Awards from the Fund are made to British scientists for distinguished work in such fields as fuel economy, chemical engineering and metallurgy, in which Sir George Beilby's special interests lay. In general, the awards are not made to senior investigators but are granted as an encouragement to relatively young men who have done independent work of exceptional merit over a period of years. The administrators intend to review the character, frequency and conditions of awards from the Fund, and have decided not to consider any further awards until early in 1960.

\section{Institution of Mining and Metallurgy : Awards}

THE Institution of Mining and Metallurgy has announced the following awards : The Gold Medal of the Institution for 1957 to Dr. J. F. Thompson, chairman of the International Nickel Company of Canada, for distinguished services to metallurgical science, research and practice, with special reference to the nickel industry; Honorary Membership of the Institution has been conferred on Mr. R. Annan for outstanding services to the mining industry and to the Institution; on Dr. F. .Dixey for services to the science of geology and in particular of his work in reorganizing the Colonial Geological Surveys; and on Mr. M. A. E. Mawby for valuable services to the mining industry in Australia and to the Institution; 'The Consolidated Gold Fields of South Africa, Ltd.' Gold Medal for 1956-57 jointly to Mr. K. E. Mackay and Mr. J. D. Johnson for their paper entitled "The Development of the Bancroft Mine" (Trans. Inst. Min. Metall., 66) and 'The Consolidated Gold Fields of South Africa, Ltd.' Premium of forty guineas for 1956-57 to Mr. J. Morison Caw for his paper entitled "Control of Air Pressures as an aid to Fight Mine Fires" (Trans. Inst. Min. Metall., 66) ; The Arthur Claudet Student's Prize to Dr. J. K. Almond for his part-authorship of the paper entitled "Pulp Density Measurement with Ultrasonics" (Trans. Inst. Min. Metall., 66); and The William Frechville Student's Prize to Dr. Barry Scott for his part-authorship of the paper entitled "Stratigraphical and Structural Ore Controls on the Slitt Vein at Heights Mine, Weardale, County Durham" (Trans. Inst. Min. Metall., 66).

\section{Royal Meteorological Society : Honorary Members and Awards}

The following have recently been elected to honorary membership of the Royal Meteorological Society: Prof. Tor Bergeron, professor of meteorology, University of Upsala, distinguished for his contribution to synoptic meteorology and climatology in relation to the polar front, and for his elaboration of the theory of the generation of precipitation through the co-existence of ice and water in clouds; Sir David Brunt, distinguished for his contributions in many fields of meteorology, particularly in his studies of radiation and in the dynamics of the free atmosphere; Mr. E. Gold, distinguished for his early studies of the radiation balance of the atmosphere and on barometric gradient and wind force and for his services to synoptic meteorology as president of the Commission for Synoptic Meteorology from its foundation in 1920 until 1947; Prof. Sverre Petterssen, professor of meteorology, University of Chicago, a distinguished synoptic meteorologist of the Bergen school and president of the American Meteorological Society ; Sir George Simpson, meteorologist to Capt. Scott's antarctic expedition (1912-13), Imperial meteorologist, India (1907-20), director of the Meteorological Office, London (1920-38), author of influential contributions to the knowledge of atmospheric electricity, palæoclimatology, the radiation balance of the Earth and atmospheric aerosols.

The following awards have also been announced : the Buchan Prize to Dr. R. M. Goody for his outstanding contributions to the theory and observations of the absorption and emission of radiation in the atmosphere; and the Hugh Robert Mill Medal and Prize to Mr. L. C. W. Bonacina, whose interest in precipitation in Britain has covered a period of more than fifty years.

\section{Science and the State}

IN his presidential address to the Institution of Chemical Engineers on "Science and the State" on April 30, Sir Hugh Beaver emphasized the dominant part that science and technology have come to play in national policy, while the influence of the State in the lives of ordinary people and on the use of scientists and the direction of research is also increasing. The vital problem is how these two forces can be brought to operate jointly and purposefully to achieve success. Sir Hugh addressed himself to the question whether our present arrangements are adequate and effective to ensure that the State can mobilize to the full the resources of science. He distinguished four aspects: the production of an adequate supply of scientists and technologists; the promotion of adequate research; securing that the results of research are known and applied; and the furtherance of development. Sir Hugh was concerned mainly with the first two, and in discussing education, stressed the importance of science teachers, a continuing shortage of which would ultimately stultify all other efforts to increase our supply of scientists and technologists.

Sir Hugh maintained that in education we have no concrete national policy nor the national organization to secure one, and in regard to research he 